\title{
Bolted joints in the running gears of rail vehicles
}

\section{Połączenią śrubowe w układach biegowych pojazdów szynowych}

\begin{abstract}
The article presents the issues related to proper choice of bolted joints existing in the running gears of rail vehicles, particularly those of freight cars. The bolted joint, being a connecting member, plays an important role decisive for the driving safety. This problem is often underestimated, nevertheless, it requires closer attention to be paid by rail vehicle

W artykule przedstawiono problematykę zwiqzanq z właściwym doborem połqczeń śrubowych w układach biegowych pojazdów szynowych, zwłaszcza w przypadku wagonów towarowych. Połaczenia śrubowe, jako element złaczny petniq istotna role, decydujaca o bezpieczeństwie jazdy. Zagadnienie to jest często niedoceniane, ale wymaga poświęcenia większej uwagi konstruktorów pojazdów szynowych, zwłaszcza na etapie projektowania.
\end{abstract}

\section{INTRODUCTION}

Correct choice of the bolted joints is not at all an easy task, as is shown by operational practice. It requires professional knowledge of not only the designers but also the carriers, inclusive of the personnel engaged in repairs of the rolling stock. The bolted joints used in the rail vehicles and infrastructure devices, e.g. in railroad switches or track brakes, are subjected to extremely severe operating conditions, even despite proper installation. Among the heavy operating conditions of bolted joints, specific to railway conditions, may be included the following:

\section{WSTEPP}

Prawidłowy dobór połączeń śrubowych jak wykazuje praktyka eksploatacyjna nie jest wcale prostym zagadnieniem, wymaga fachowej wiedzy nie tylko konstruktorów, ale przewoźników, wraz z personelem prowadzącym naprawy taboru kolejowego. Połączenia śrubowe stosowane $\mathrm{w}$ pojazdach szynowych oraz $\mathrm{w}$ urządzeniach infrastruktury $\mathrm{np}$. w rozjazdach lub hamulcach torowych podlegają bardzo trudnym warunkom eksploatacyjnym, nawet przy zastosowaniu prawidłowych warunków montażowych. Do trudnych warunków eksploatacyjnych połączeń śrubowych, 
- the effects of varying weather conditions, inclusive of the rain, snow, icing, frostiness, etc.;

- ambient temperature $-25^{\circ} \div+40^{\circ} \mathrm{C}$;

- influence of $\mathrm{SO}_{2}, \mathrm{SO}_{3}$ or $\mathrm{CO}_{2}$, industrial atmosphere, corrosion promoting salt solutions;

- vibration of wide frequency and amplitude spectrum;

- extraordinary static loads;

- impact loads (particularly dangerous for bolted joints of the wheelsets and for unsprung parts of the running gear);

- variable dynamic loads;

- lack of proper access to many bolted joints, precluding visual check of their current technical condition during the inspections.

According to available operational data, the damages of bolted joints are caused by the following corrosion types:

- $\quad$ surface corrosion (approx. 27\% of the cases);

- $\quad$ stress corrosion (approx. $23 \%$ of the cases);

- crevice corrosion (approx. 14\% of the cases);

- others (approx. 36\% of the cases).

The condition when the fatigue strength of the bolts is very low and amounts only to a fraction of the fatigue limit of a smooth plate [3] for a cut, ground or milled thread, should be considered as a serious warning.

Hence, a rail vehicle cannot be compared to a stationary device operating under much more favorable and predictable conditions. Another problem lies in the trend of gradual extension of inter-repair periods at all the P1-P5 levels. A major problem of the railway technology consists in loosening of the bolted joint and tendency to unscrew. Loosening of the bolted joint results usually in decrease in the tension force " $F_{Z}$ " of the joint. Decrease in the tension force caused by the operational forces occurs in result of settling or plastic deformation of the elements belonging to the joint or structural parts.

In such a case the following recommendations aimed at avoiding loosening of the bolted joints are known, inclusive of the following:

$>$ controlling the calculated bolt tensioning force by proper lubrication, the use of a torque wrench. The bolt torque (tightening torque) and the tolerances should comply with the design documentation.

$>$ ensure high smoothness (low roughness) and cleanliness of the joined surfaces;

$>$ increase in the ratio of stretched length to diameter $1 / \mathrm{d}>4$;

$>$ avoid bending of the bolt;

$>$ reduction of relative movements between the joined elements subjected to tension;

$>$ do not exceed the unit surface pressure of the basic material; specyficznych dla warunków kolejowych można zaliczyć:

- oddziaływanie zmiennych warunków klimatycznych, do których można zaliczyć opady deszczu, śniegu, oblodzenie, szron itd.,

- temperatura otoczenia $-25^{\circ} \div+40^{\circ} \mathrm{C}$,

- działanie $\mathrm{SO}_{2}, \mathrm{SO}_{3}$ lub $\mathrm{CO}_{2}$, atmosfery przemysłowej, roztworów soli sprzyjających korozji,

- drgania, wibracje o szerokim spektrum częstotliwości i amplitud,

- obciążenia statyczne nadzwyczajne,

- obciazżenia o charakterze udarowym (szczególnie groźne dla połączeń śrubowych $\mathrm{w}$ zestawach kołowych oraz na nieusprężynowanych częściach układu biegowego),

- obciążenia dynamiczne o charakterze zmiennym,

- brak odpowiedniego dostępu wielu połączeń śrubowych do kontroli wizualnej w celu sprawdzenia bieżącego stanu technicznego podczas przeglądów.

Jak wynika $\mathrm{z}$ danych eksploatacyjnych uszkodzenia połączeń śrubowych pochodzą od następujących rodzajów korozji:

- korozji powierzchniowej (ok. 27\% przypadków),

- $\quad$ korozji naprężeniowej (ok. 23\% przypadków),

- $\quad$ korozji szczelinowej (ok. $14 \%$ przypadków),

- pozostałe rodzaje korozji (ok. 36\% przypadków).

Jako poważne ostrzeżenie można traktować stwierdzenie, że wytrzymałość zmęczeniowa śrub jest bardzo niska i wynosi przy naciętym, szlifowanym lub wyfrezowanym gwincie tylko ułamek granicy zmęczenia gładkiej płyty [3].

Pojazdu szynowego nie można więc porównywać do urządzenia stacjonarnego, które pracuje $\mathrm{w}$ znacznie bardziej korzystnych i przewidywalnych warunkach. Kolejnym problemem jest tendencja stopniowego wydłużenia okresów między-naprawczych na wszystkich poziomach P1-P5. Największym problemem w technice kolejowej, jest zjawisko luzowania się połączenia śrubowego (niem. „das Lockern.”) oraz tendencje do odkręcania się (niem. „Losdrehen.”). Przez luzowanie połączenia śrubowego rozumie się najczęściej spadek siły napinającej „, $F_{Z}$ ” połączenia śrubowego. Spadek siły napinającej „,FZ” odbywa się w wyniku zjawiska osiadania (niem. „,das Setzen”) lub w wyniku odkształcenia plastycznego elementów wchodzących w skład połączenia lub części konstrukcyjnych pod wpływem sił eksploatacyjnych.

$\mathrm{W}$ takim przypadku znane są następujące zalecenia, aby uniknąc luzowania połączeń śrubowych, do których można zaliczyć:

utrzymanie obliczeniowej siły napinającej śrubę w sposób kontrolowany tzn. poprzez 
$>$ the use of corrosion protection of the screws, nuts, washers.

The general recommendations useful in the railway technology should include the use of self-locking nuts and washers. The crown nuts should be eliminated as soon as possible, since they seem at present to be an outdated and uneconomical solution. What concerns the recommendations aimed at designing the bolted joints with consideration of pure tension, the designer must be aware that the bolts are often subjected to complex loads of varying direction, value and nature of variability. Bending of the bolt cannot be fully eliminated, nonetheless, it may be decreased by reducing the bending moment arms. Location of the bolted joint in the vehicle is extremely important. The acceleration values resulting from random vibration depend on whether the bolted joint is located on the axle, on the bogie (on the running gear) or on the vehicle body. Due to the lack of other data, the European Standard PN-EN 61373: 2011 [4] is very helpful. Two Tables 1 and 2 are quoted based on it. Table 1 presents the parameters related to the conditions of functional random vibration tests, while Table 2 includes the simulation results of the durability tests in case of increased random vibration level.

Table 1

Test severity and frequency range for functional random vibration tests according to PN-EN 61373:2011 [4]

Tablica 1

Ostrość badania i zakres częstotliwości dla funkcjonalnych badań losowych wg PN-EN 61373:2011 [4]

\begin{tabular}{|c|c|c|c|c|}
\hline $\begin{array}{c}\text { L.p. } \\
\text { Item No }\end{array}$ & $\begin{array}{c}\text { Kategoria/Klasa } \\
\text { Miejsce monta- } \\
\text { żu } \\
\text { Category/Class } \\
\text { Mounting } \\
\text { location }\end{array}$ & $\begin{array}{c}\text { Kierunek } \\
\text { Orientation }\end{array}$ & $\begin{array}{c}\text { Przyspieszenie: } \\
\text { wartość sku- } \\
\text { teczna } \\
\text { Acceleration } \\
\text { RMS }\left[\mathrm{m} / \mathrm{s}^{2}\right]\end{array}$ & $\begin{array}{c}\text { Zakres częstotli- } \\
\text { wości Frequency } \\
\text { range }\end{array}$ \\
\hline \multirow{3}{*}{1} & 1 & $\begin{array}{l}\text { pionowy } \\
\text { vertical }\end{array}$ & 0,750 & \multirow{3}{*}{$\begin{array}{l}\text { Fig.2 acc. to PN- } \\
\text { EN } 61373: 2011 \text { [4] }\end{array}$} \\
\hline & $\begin{array}{l}\text { klasa A } \\
\text { Class A }\end{array}$ & poprzeczny transverse & 0,370 & \\
\hline & $\begin{array}{c}\text { montaż na } \\
\text { nadwoziu } \\
\text { body mounted }\end{array}$ & wzdłużny longitudinal & 0,500 & \\
\hline \multirow{3}{*}{2} & 1 & $\begin{array}{l}\text { pionowy } \\
\text { vertical }\end{array}$ & 1,01 & \multirow{3}{*}{$\begin{array}{l}\text { Fig. } 3 \text { acc. to PN- } \\
\text { EN } 61373: 2011 \text { [4] }\end{array}$} \\
\hline & $\begin{array}{l}\text { klasa B } \\
\text { Class B } \\
\end{array}$ & poprzeczny transverse & 0,450 & \\
\hline & $\begin{array}{c}\text { montaż na } \\
\text { nadwoziu } \\
\text { body mounted }\end{array}$ & wzdłużny longitudinal & 0,700 & \\
\hline \multirow{3}{*}{3} & 2 & $\begin{array}{l}\text { pionowy } \\
\text { vertical }\end{array}$ & 5,40 & \multirow{3}{*}{$\begin{array}{l}\text { Fig.4 acc. to PN- } \\
\text { EN } 61373: 2011 \text { [4] }\end{array}$} \\
\hline & - & poprzeczny transverse & 4,70 & \\
\hline & $\begin{array}{c}\text { montaż na } \\
\text { wózku } \\
\text { boogie mounted }\end{array}$ & wzdłużny longitudinal & 2,50 & \\
\hline \multirow[b]{3}{*}{4} & 3 & $\begin{array}{l}\text { pionowy } \\
\text { vertical }\end{array}$ & 38,0 & \multirow{3}{*}{$\begin{array}{l}\text { Fig.5 acc. to PN- } \\
\text { EN } 61373: 2011 \text { [4] }\end{array}$} \\
\hline & - & poprzeczny transverse & 34,0 & \\
\hline & $\begin{array}{c}\text { montaż na osi } \\
\text { zestawu kołowe- } \\
\text { go } \\
\text { axle mounted }\end{array}$ & wzdłużny longitudinal & 17,0 & \\
\hline
\end{tabular}

prawidłowe smarowanie, zastosowanie klucza dynamometrycznego, przy czym moment napinający (zwany momentem dokręcenia) śrubę wraz z tolerancjami powinien wynikać z dokumentacji konstrukcyjnej,

> powierzchnie łączone o dużym stopniu gładkości (niskiej chropowatości) i czystości,

$>$ zwiększyć stosunek długości napinanej do średnicy $1 / d>4 \quad$ (niem. ,Klemmlängeverhältniß’”),

$>$ unikać obciążeń śruby na obciążenie zginające,

$>$ zmniejszenie względnych ruchów pomiędzy napinanymi elementami łączonymi,

$>$ nie przekraczać jednostkowych nacisków powierzchniowych materiału zasadniczego,

$>$ zastosowanie ochrony przeciwkorozyjnej dla śrub, nakrętek, podkładek.

Do ogólnych zaleceń, przydatnych dla techniki kolejowej należy uwzględnić stosowanie nakrętek i podkładek samo-zabezpieczających i możliwe szybkie wyeliminowanie nakrętek koronowych, które w obecnym czasie wydają się być rozwiązaniem anachronicznym i nie- ekonomicznym. W przypadku zalecenia dotyczącego, projektowania obciążeń śrubowych na czyste rozciaganie, konstruktor musi zdawać sobie sprawę że w wielu przypadkach obciążenia śrubowe podlegają obciążeniom złożonym, co do kierunku i wartości, charakteru zmienności. Obciążeń śruby na zginanie nie można całkowicie wyeliminować, natomiast można je ograniczyć, poprzez redukcję ramion

działania momentu zginającego. Niezwykle ważne jest w jakim miejscu na pojeździe znajduje się połączenie śrubowe np. czy znajduje się na osi, czy na wózku (na układzie biegowym) czy na nadwoziu pojazdu. Wielkość przyspieszeń, wynikających $\mathrm{z}$ wibracji losowych jest ważna $\mathrm{z}$ punktu widzenia lokalizacji połączenia śrubowego. $Z$ uwagi na brak innych danych, bardzo pomocna jest norma europejska PN-EN 61373:2011 [4], na podstawie której przytoczono dwie tablice 1 i 2. Tablica 1 przedstawia parametry, związane $\mathrm{z}$ warunkami funkcjonalnego badania wibracji losowych, natomiast tablica $2 \mathrm{z}$ badaniami symulacyjnymi trwałości przy zwiększonym poziomie wibracji losowych. 
Test severity and frequency range with increased level of random vibration, according to PN-EN 61373:2011 [4]

Ostrość badania i zakres częstotliwości przy zwiększonym poziomie wibracji losowych wg PN-EN 61373:2011 [4]

Tablica 2

\begin{tabular}{|c|c|c|c|c|}
\hline $\begin{array}{l}\text { L.p. } \\
\text { Item No }\end{array}$ & $\begin{array}{c}\text { Kategoria/Klasa } \\
\text { Miejsce montażu } \\
\text { Category/Class } \\
\text { Mounting location } \\
\end{array}$ & $\begin{array}{l}\text { Kierunek } \\
\text { Orientation }\end{array}$ & $\begin{array}{c}\text { Przyspieszenie: wartość } \\
\text { skuteczna } \\
\text { Acceleration } \\
\text { RMS }\left[\mathbf{m} / \mathbf{s}^{2}\right] \\
\end{array}$ & $\begin{array}{l}\text { Zakres częstotliwości } \\
\text { Frequency range }\end{array}$ \\
\hline \multirow{3}{*}{1} & 1 & $\begin{array}{l}\text { pionowy } \\
\text { vertical }\end{array}$ & 4,25 & \multirow{3}{*}{$\begin{array}{l}\text { Fig. } 2 \text { acc. to PN-EN } \\
61373: 2011[4]\end{array}$} \\
\hline & $\begin{array}{l}\text { klasa A } \\
\text { Class A }\end{array}$ & poprzeczny transverse & 2,09 & \\
\hline & $\begin{array}{c}\text { montaż na nadwoziu } \\
\text { body mounted }\end{array}$ & wzdłużny longitudinal & 2,83 & \\
\hline \multirow{3}{*}{2} & 1 & $\begin{array}{l}\text { pionowy } \\
\text { vertical }\end{array}$ & 5,72 & \multirow{3}{*}{$\begin{array}{l}\text { Fig.3 acc. to PN-EN } \\
61373: 2011[4]\end{array}$} \\
\hline & $\begin{array}{l}\text { klasa B } \\
\text { Class B }\end{array}$ & poprzeczny transverse & 2,55 & \\
\hline & $\begin{array}{c}\text { montaż na nadwoziu } \\
\text { body mounted }\end{array}$ & wzdłużny longitudinal & 3,96 & \\
\hline \multirow{3}{*}{3} & 2 & $\begin{array}{l}\text { pionowy } \\
\text { vertical }\end{array}$ & 30,6 & \multirow{3}{*}{$\begin{array}{l}\text { Fig.4 acc. to PN-EN } \\
61373: 2011[4]\end{array}$} \\
\hline & - & poprzeczny transverse & 26,6 & \\
\hline & $\begin{array}{c}\text { montaż na wózku } \\
\text { boogie mounted }\end{array}$ & wzdłużny longitudinal & 2,50 & \\
\hline \multirow{3}{*}{4} & 3 & $\begin{array}{l}\text { pionowy } \\
\text { vertical }\end{array}$ & 38,0 & \multirow{3}{*}{$\begin{array}{l}\text { Fig.5 acc. to PN-EN } \\
61373: 2011[4]\end{array}$} \\
\hline & - & poprzeczny transverse & 34,0 & \\
\hline & $\begin{array}{c}\text { montaż na osi zestawu } \\
\text { kołowego } \\
\text { axle mounted }\end{array}$ & wzdłużny longitudinal & 17,0 & \\
\hline
\end{tabular}

Category 1 - Body mounted;

Class A - Body mounted, the devices and elements located directly on or under the vehicle body;

Class B - The whole equipment is mounted inside the device housing, located directly on or under the vehicle body;

Category 2 - Bogie mounted;

The cabs, equipment and devices, inclusive of the ones mounted on the rail vehicle boogie;

Category 3 - Axle mounted;

The subassemblies, devices and components or assemblies mounted on the rail vehicle wheelset. The tests carried out in accordance with the above standards can be divided into stationary tests, performed at the test stands, and the field (in-service) tests. Although the PN-EN 61373: 2011 [4] standard refers to the tests of random vibration and single impact loads for pneumatic, electric and electronic components/devices mounted in the rolling stock, it must also be valid for their fasteners, inclusive of the bolted joints. The random vibration is a validated method used for approval of the pneumatic, electrical or electronic equipment/components.

2. DESCRIPTION OF THE ISSUES RELATING TO LOOSENING OF THE BOLTED JOINTS

\subsection{Description of the computation method}

The reasons for loosening of bolted joints are:

$>$ oscillations, vibrations and dynamic loads;

$>$ insufficient preload force, particularly in case
Kategoria 1 - Montowane na nadwoziu

Klasa A-Montowane na nadwoziu, urządzenia i elementy bezpośrednio na lub pod pudłem pojazdu

Klasa B- Całe wyposażenie montowane wewnątrz skrzyni urządzenia, która znajduje się z kolei bezpośrednio na lub pod pudłem pojazdu

Kategoria 2 Montowane na wózku

Kabiny, urządzenia i elementy i elementy, które są montowane na wózku pojazdu kolejowego

Kategoria 3 Montowanie na osi

Podzespoły, urządzenia i elementy lub zespoły, które są montowane na zestawie kołowym pojazdu kolejowego. Badania wg ww. normy dzielą się na badania stacjonarne na stanowiskach badawczych oraz badania poligonowe (eksploatacyjne). Pomimo, że norma PNEN 61373:2011 [4] odnosi się do badań wibracji losowych i pojedynczych obciążeń udarowych dla elementów/urządzeń pneumatycznych, elektrycznych i elektronicznych, montowanych w taborze kolejowym, to musi odnosić się również do ich elementów złącznych, w tym połączeń śrubowych. Wibracja losowa jest uznaną metodą, stosowaną do homologacji urządzeń/elementów pneumatycznych, elektrycznych lub elektronicznych.

\section{OPIS PROBLEMATYKI LUZOWANIA SIE POLĄCZEŃ ŚRUBOWYCH}

2.1. Opis metodyki obliczeniowej

Przyczynami luzowania połączeń śrubowych są:

$>$ drgania, wibracje i obciążenia dynamiczne,

$>$ niewystarczający zacisk wstępny (siła zacisku wstępnego), zwłaszcza przy ekscentrycznie 
of eccentrically loaded bolted joints, resulting in slippage between the joined surfaces;

reduction of $\mathrm{F}_{\mathrm{V}}$ initial preload force from initial $\mathrm{F}_{\mathrm{V} 1}$ to $\mathrm{F}_{\mathrm{V} 2}$ by settlement phenomenon, illustrated in Fig. 1.

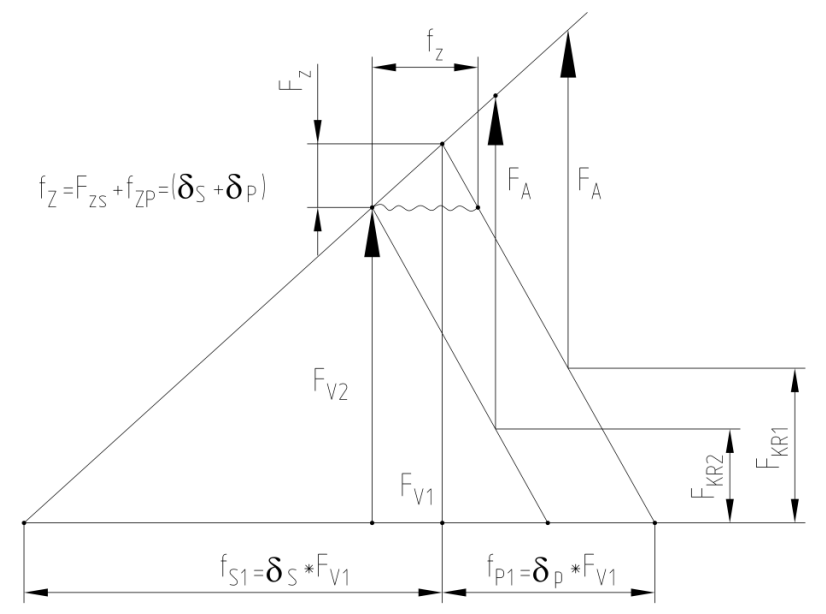

Fig.1. Reduction of the $\mathbf{F}_{\mathbf{V}}$ preload force and residual compression force $\mathbf{F}_{\mathbf{K R}}$

Rys.1. Zmniejszenie siły napięcia wstępnego $\mathbf{F}_{\mathbf{V}}$ i resztkowa siła docisku $\mathbf{F}_{\mathbf{K R}}$

The notations in Fig.1:

$\mathrm{D}_{\mathrm{m}}-$ active diameter related to the friction moment in the bolt head or at the nut contact surface;

$\mathrm{E}$ - elastic modulus of the material (Young's modulus);

$\mathrm{F}_{\mathrm{A}}$ - axial component of the operating force;

$\mathrm{F}_{\mathrm{KR}}-$ residual compression force;

$\mathrm{F}_{\mathrm{QR}}$ - transverse force, directed perpendicularly to the bolt axis;

$\mathrm{F}_{\mathrm{V}}$ - the bolt preload force;

I - moment of inertia;

$\mathrm{M}_{\mathrm{L}}$ - loosening moment of the bolted joint;

$\mathrm{P}$ - thread pitch;

A - transverse amplitude;

a - height;

a - height of the convex locking edge;

$\mathrm{d}$ - thread diameter;

$\mathrm{d}_{2}-$ thread pitch diameter;

f- limiting displacement;

$f_{P}$ - change in the length of the tense sheets;

$\mathrm{f}_{\mathrm{S}}$ - change in the bolt length;

$\mathrm{f}_{\mathrm{Z}}$ - settlement;

$f_{Z P}-$ settlement of the tense sheets;

$\mathrm{f}_{\mathrm{ZS}}-$ settlement of the bolt;

$\mathrm{L}_{\mathrm{K}}$ - clamp length;

$\mathrm{S}$ - displacement of the tense parts subjected to transverse load;

$\delta_{\mathrm{P}}-$ susceptibility (elasticity) of the tense sheets;

$\delta_{\mathrm{S}}-$ susceptibility (elasticity) of the bolt;

$\mu$ - friction coefficient (general);

$\mu_{\mathrm{G}}-$ friction coefficient of the bolt thread;

$\mu_{\mathrm{K}}-$ friction coefficient of the nut contact surface;

$\phi$ - lead angle.

The loosening moment for the bolted joint may be determined from the following formula (1):

Since normally the friction shall not be less than the lead angle even under the best lubrication conditions, the expression in parentheses will be positive. Hence, loosening may arise only when the preload force drops to zero due to plastic deformation of the stretching or obciążonych połączeń śrubowych, wywołujących poślizgi pomiędzy powierzchniami łączonymi,

$>$ zmniejszenie siły zacisku wstępnego $\mathrm{F}_{\mathrm{V}} \mathrm{z}$ początkowej $F_{\mathrm{V} 1}$ do $F_{\mathrm{V} 2}$ przez tzw. osiadanie (niem. „das Setzen ”). Zjawisko to jest zilustrowane na rys.1.

Oznaczenia użyte na rys.1:

$\mathrm{D}_{\mathrm{m}}$ - czynna średnica dla momentu tarcia w łbie śruby lub na powierzchni oparcia nakrętki,

E- moduł sprężystości materiału (moduł Younga),

$\mathrm{F}_{\mathrm{A}}$ - składowa poosiowa siły eksploatacyjnej,

$\mathrm{F}_{\mathrm{KR}}-$ resztkowa siła docisku,

$\mathrm{F}_{\mathrm{QR}}$ - sił poprzeczna, skierowana $\mathrm{w}$ kierunku prostopadłym do osi śruby,

$\mathrm{F}_{\mathrm{V}^{-}}$siła napięcia wstępnego śruby,

I- moment bezwładności,

$\mathrm{M}_{\mathrm{L}}$ - moment siły luzowania połączenia śrubowego,

P- wznios gwintu,

a-amplituda poprzeczna,

a'- wysokość,

a-wysokość wypukle wyoblonej krawędzi blokującej,

d-średnica gwintu,

$\mathrm{d}_{2}$ - średnica podziałowa gwintu,

f- przemieszczenie graniczne,

$\mathrm{f}_{\mathrm{P}}$ - zmiana długości napiętych blach,

$\mathrm{f}_{\mathrm{S}}$ - zmiana długości śruby,

$\mathrm{f}_{\mathrm{Z}^{-}}$wartość osiadania,

$\mathrm{f}_{\mathrm{ZP}}-$ wartość osiadania napiętych blach,

$\mathrm{f}_{\mathrm{ZS}}$ - wartość osiadania śruby,

$\mathrm{L}_{\mathrm{K}^{-}}$długość zacisku,

s- długość przemieszczenia napiętych części pod obciążeniem poprzecznym,

$\delta_{\mathrm{P}}$ - podatność (elastyczność) napiętych blach,

$\delta_{\mathrm{S}}$-podatność (elastyczność) śruby,

$\mu$ - współczynnik tarcia (ogólnie),

$\mu_{\mathrm{G}}$-współczynnik tarcia gwintu śruby,

$\mu_{K^{-}}$współczynnik tarcia powierzchni oparcia nakrętki,

$\phi$ - kąt wzniosu linii gwintowej.

Moment luzujący dla połączenia śrubowego można wyznaczyć z następującego wzoru:

$$
\mathrm{M}_{\mathrm{L}}=\mathrm{F}_{\mathrm{V}} \cdot\left(\frac{\mathrm{d}_{2}}{2} \cdot \tan \left(-\varphi+1,15 \cdot \mu_{\mathrm{G}}\right)+\frac{\mathrm{D}_{\mathrm{m}}}{2} \cdot \mu_{\mathrm{K}}\right)
$$

Ponieważ w normalnym przypadku nawet przy najlepszych warunkach smarowania tarcie nie będzie mniejsze niż kąt wzniosu gwintu, wyrażenie w nawiasie nie będzie równe lub mniejsze od zera. A więc luzowanie może wystąpić tylko wtedy, jeśli z powodu deformacji plastycznych części napinanych lub napiętych, siła napięcia wstępnego spadnie do zera. Ta zasada obowiązuje ciągle dla połączeń śrubowych, które są obciążone dynamicznie w kierunku poosiowym.

Jeżeli spadek napięcia wstępnego w połączeniu śrubowym występował jedynie wskutek „osiadania”, to wówczas może być:

$>$ uwzględniony na drodze analitycznej za pomocą obliczeń i

> opanowany lub przynajmniej zmniejszony za pomocą odpowiednich środków technicznych. 
already stretched parts. This rule is always valid for the bolted joints dynamically loaded in the axial direction.

If the preload of the bolted joint drops only due to "settling", the problem may be:

$>$ taken into account analytically by calculation and

$>$ controlled or at least reduced by appropriate technical means.

Such technical means included initially the spring washers and shaped spring washers.

The required elastic or residual elastic forces in case of the displacement of $20 \mu \mathrm{m}$ and subsequent relieving of the bolted joint are quoted in the German Standard DIN 267, part 26 [6].

Nevertheless, the conditions related to the bolted joints dynamically loaded in the transverse direction to the longitudinal axis of the bolt differ from the ones mentioned before. In this case, relative displacements occur between the tense parts. These relative movements bend the bolt with an amplitude of "a" shown in Fig. 2. Once the limiting displacement " $\mathrm{f}$ " is reached, the friction force is reduced. The condition of correct operation of the bolted joint is as follows:

$$
\mathrm{s}<\mathrm{f}
$$

If the bolt is subjected to couple of forces FQP applied perpendicularly to the longitudinal axis, the bolt automatically loosens, provided that the preload force is insufficient and enables relative movements causing reduction of the thread self-locking and friction arising between the bolt head or spring washer.

Hence, a slippage occurs and the loosening moment takes a negative value defined as the "internal loosening moment" according to the formula:

$$
\mathrm{M}_{\mathrm{Li}}=\mathrm{F}_{\mathrm{V}} \cdot \frac{\mathrm{d}}{2} \cdot(\tan (-\varphi))=-\mathrm{F}_{\mathrm{V}} \cdot \frac{\mathrm{d}}{2} \cdot(\tan (\varphi))
$$

Taking into account the relationship

one obtains:

$$
\begin{aligned}
\varphi & =\frac{-P}{\pi \cdot d^{2}} \\
M_{L} & =\frac{-F_{V} \cdot P}{2 \pi}
\end{aligned}
$$

This condition is met once the theoretical limiting displacement is reached that may be determined approximately.

$$
\mathrm{s}=\frac{\mathrm{F}_{\mathrm{v}} \cdot \mu_{\mathrm{k}} \cdot \mathrm{L}_{\mathrm{k}}^{3}}{12 \mathrm{EI}}
$$

The formula (6) shows that the displacement amplitude is determined by the following factors:

$>$ preload force $\mathbf{F}_{\mathbf{V}}$ of the bolted joint;

$>$ friction coefficient $\mu_{\mathrm{K}}$ of the nut surface;

$>\mathbf{L}_{\mathbf{K}^{-}}$clamp length of the connected elements $\left(\mathbf{L}_{\mathbf{K}}=\Sigma \mathbf{L}_{\mathrm{KI}}\right)$;

$>$ diameter $\mathbf{d}$ of the thread of the bolt;

$>$ modulus of elasticity of the connected elements $\mathbf{E}$.
Takim środkiem konstrukcyjnym na początku były podkładki sprężyste oraz kształtowe podkładki sprężyste (niem. „federnde Sperrkantringe”).

Niezbędne siły sprężyste względnie szczątkowe (resztkowe) siły sprężyste (po przemieszczeniu, wynoszącym $20 \mu \mathrm{m}$, po odciążeniu połączenia śrubowego są przytoczone w normie niemieckiej DIN 267, część $26[6]$.

Inaczej jednakże kształtują się warunki dla dynamicznie obciążonych połączeń śrubowych w kierunku poprzecznym do osi wzdłużnej śruby. W tym przypadku działają przemieszczenia względne pomiędzy napinanymi częściami. Te ruchy względne wyginają śrubę $z$ amplitudą ,a.”, co jest pokazane na rys.2. Po osiagnięciu przemieszczenia granicznego „f” siła tarcia zostaje zredukowana. Warunkiem poprawnej pracy złącza śrubowego jest spełnienie warunku:

$$
\mathrm{s}<\mathrm{f}
$$

Jeśli śruby poddane są działaniu pary sił $\mathrm{F}_{\mathrm{QP}}$, które działaja prostopadle $\mathrm{w}$ kierunku do osi wzdłużnej, wówczas dochodzi da samoczynnego luzowania, jeśli siła zacisku wstępnego posiada niedostateczną wartość i występują ruchy względne , które doprowadzają do redukcji samohamowności gwintu i tarcia pomiędzy łbem śruby względnie podkładki sprężystej.

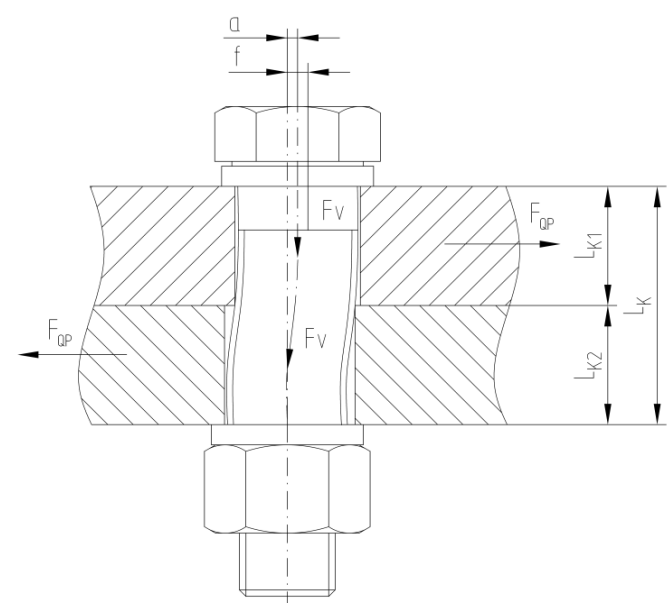

Fig.2. Bolted joint connecting two sheets, transversely loaded by a couple of forces $\mathrm{F}_{\mathrm{QP}}$

Rys.2. Połączenie śrubowe, łączące dwie blachy, obciążone w kierunku poprzecznym parą sił $\mathrm{F}_{\mathrm{QP}}$

Zatem powstaje poślizg, a moment luzujący otrzymuje wartość ujemną którą określa się jako „wewnętrzny moment luzujący" zgodnie ze wzorem:

$$
\mathrm{M}_{\mathrm{Li}}=\mathrm{F}_{\mathrm{V}} \cdot \frac{\mathrm{d}}{2} \cdot(\tan (-\varphi))=-\mathrm{F}_{\mathrm{V}} \cdot \frac{\mathrm{d}}{2} \cdot(\tan (\varphi))
$$

Uwzględniając zależność:

otrzymuje się:

$$
\varphi=\frac{-P}{\pi \cdot d^{2}}
$$

$$
M_{L}=\frac{-F_{V} \cdot P}{2 \pi}
$$




\subsection{Asymmetric load of the bolted joints}

As demonstrated by the operational experience, the bolted joints are in practice loaded and tensioned asymmetrically with regard to the bolt axis. Hence, the classic "preload triangle" ceases to apply and is replaced by the diagram presented in Fig. 3.

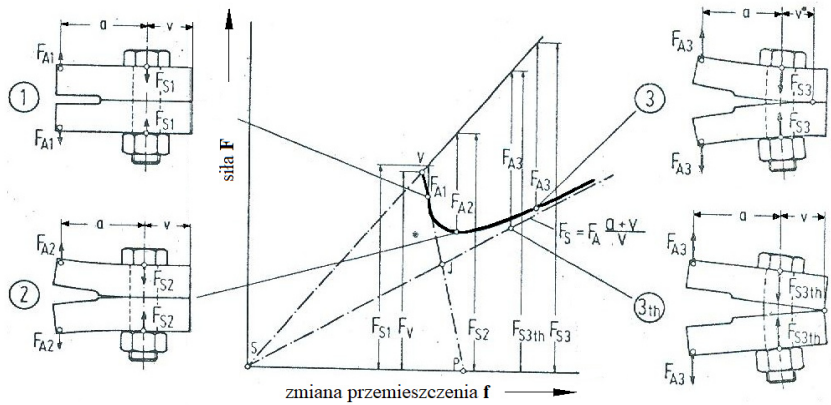

Fig.3. Force-displacement graph in eccentrically loaded bolted joints

Rys.3. Wykres siła-przemieszczenie w ekscentrycznie obciążonych połączeniach śrubowych

The symbols used in Fig. 3:

$\mathrm{F}$ - force (general);

$\mathrm{F}_{\mathrm{A}}$ - operational force acting along the bolt axis;

$\mathrm{F}_{\mathrm{Aab}}$ - eccentric axial force at the decline limit;

$\mathrm{F}_{\mathrm{S}}$ - compressive force in the bolt;

$\mathrm{F}_{\mathrm{SA}}$ - additional force in the bolt;

$\mathrm{F}_{\mathrm{a} 10 ; 50 ; 90}$ - force amplitude corresponding to vibration with $10 \%, 50 \%$ and $90 \%$ crack probability;

$\mathrm{F}_{\mathrm{m}}-$ static force with $10 \%, 50 \%$ and $90 \%$ crack probability;

$\mathrm{F}_{\mathrm{V}}$ - preload force;

$\mathrm{F}_{0 ; 2}$ - bolt force with yield strength $\mathrm{R}_{0 ; 2}$;

$\mathrm{F}_{\mathrm{Max}}-$ maximum tensile force;

$\mathrm{M}_{\mathrm{A}}-$ preload torque required while assembling (tightening torque);

$\mathrm{n}$ - the coefficient multiplied by the clamp length $1_{\mathrm{k}}$, represents the number of the zones unloaded by the axial force $\mathrm{F}_{\mathrm{A}}$;

$\mathrm{A}_{5}$ - relative elongation;

$\mathrm{Z}$ - relative reduction in cross-section area;

a - eccentricity; defined as the distance between the

force axis and the longitudinal axis of the bolted joint;

$\mathrm{D}$ - diameter of the bolt hole;

$\mathrm{f}$ - the length change caused by the $\mathrm{F}$ force;

$\mathrm{h}$ - the flange height;

$\mathrm{v}$ - the lever arm - arms of the $\mathrm{F}_{\mathrm{A} 1} ; \mathrm{F}_{\mathrm{A} 2}, \mathrm{~F}_{\mathrm{A} 3}$ and $\mathrm{F}_{\mathrm{A} 4}$ forces; $\mathrm{x}$ - variable displacement value.

Fig. 3 schematically depicts the actual relationship between the deformation and force for various values of the $\mathrm{F}_{\mathrm{A}}$ operating forces acting on an eccentrically loaded bolted joint. In the case of the assembling stage and operational case 1, the chart marked with SVP shown in Fig. 3 is valid. If the operating force $\mathbf{F}_{\mathbf{A}}$, in
Ten warunek jest spełniony po osiagnięciu teoretycznego przemieszczenia granicznego, które można wyznaczyć w sposób przybliżony.

$$
\mathrm{s}=\frac{\mathrm{F}_{\mathrm{v}} \cdot \mu_{\mathrm{k}} \cdot \mathrm{L}_{\mathrm{k}}^{3}}{12 \mathrm{EI}}
$$

Z wzoru (6) wynika, że amplitudę przemieszczenia określają następujące czynniki:

$>$ przyłożona siła napięcia wstępnego $\mathbf{F}_{\mathbf{V}}$ połączenia śrubowego,

$>$ współczynnik tarcia $\mu_{\mathrm{K}}$ powierzchni nakrętki,

$>\mathbf{L}_{\mathbf{K}^{-}}$długość zacisku elementów łączonych $\left(\mathbf{L}_{\mathrm{K}}=\Sigma \mathbf{L}_{\mathrm{KI}}\right)$,

$>$ średnica d gwintu śruby,

$>$ moduł sprężystości łączonych elementów E.

\subsection{Obciążenie asymetryczne połączeń śrubowych}

Jak dowodzą zdobyte doświadczenia eksploatacyjne połączenia śrubowe są praktyce obciążone niesymetrycznie do osi śruby i przeważnie napięte $\mathrm{w}$ sposób asymetryczny. Jeśli tak to klasyczny „trójkąt zacisku wstępnego" przestaje obowiązywać, a obowiązuje wykres przedstawiony na rys.3.

Oznaczenia użyte na rys.3:

F- siła (ogólnie),

$\mathrm{F}_{\mathrm{A}^{-}}$siła eksploatacyjna działająca wzdłuż osi śruby,

$\mathrm{F}_{\text {Aab }}$ - ekscentryczna siła osiowa na granicy spadku,

$\mathrm{F}_{\mathrm{S}^{-}}$siła ściskająca $\mathrm{w}$ śrubie,

$\mathrm{F}_{\mathrm{SA}^{-}}$dodatkowa siła $\mathrm{w}$ śrubie,

$\mathrm{F}_{\mathrm{a} 10,50,90^{-}}$amplituda sily $\mathrm{w}$ drganiach $\mathrm{z} 10 \%, 50 \% \mathrm{i}$ $90 \%$ prawdopodobieństwem pęknięcia,

$\mathrm{F}_{\mathrm{m}^{-}}$statyczne siła z $10 \%, 50 \%$ i $90 \%$ prawdopodobieństwem powstania pęknięcia,

$\mathrm{F}_{\mathrm{V}^{-}}$siła napięcia wstępnego,

$\mathrm{F}_{0,2}$-siła $\mathrm{w}$ śrubie $\mathrm{z}$ granicą plastyczności $\mathrm{R}_{0,2}$,

$\mathrm{F}_{\text {Max }}-$ maksymalna siła rozciagająca,

$\mathrm{M}_{\mathrm{A}}$-moment napięcia wstępnego dla montażu (moment dokręcania),

n- współczynnik, który jest mnożony przez długość zacisku $1_{\mathrm{k}}$, oznacza liczbę odciążonych stref przez siłę osiową $\mathrm{F}_{\mathrm{A}}$,

$\mathrm{A}_{5}$ - wydłużenie względne,

Z- przewężenie względne,

a-ekscentryczność, rozumiana jako odległość pomiędzy osią działania siły oraz osią wzdłużną połączenia śrubowego,

D-średnica otworu pod śrubę,

f- zmiana długości pod wpływem działania siły F,

h- wysokość kołnierza,

$\mathrm{v}$ - ramię dźwigni - wartości ramienia sił $\mathrm{F}_{\mathrm{A} 1}, \mathrm{~F}_{\mathrm{A} 2}, \mathrm{~F}_{\mathrm{A} 3} \mathrm{i}$ $\mathrm{F}_{\mathrm{A} 4}$,

x-zmienna długość przemieszczenia.

Rys.3 pokazuje schematycznie rzeczywiste warunki zależności odkształcenia od siły dla różnych wartości sił eksploatacyjnych $\mathrm{F}_{\mathrm{A}} \mathrm{W}$ ekscentrycznie obciążonym połączeniu śrubowym. Dla stanu montażu i przypadku eksploatacyjnego 1 obowiązuje wykres oznaczony znanymi literami SVP, zamieszczony na rys.3. Jeśli 
the beginning of the one-sided decline, exceeds the critical $\mathbf{F}_{\mathbf{A a b}}$ value, the force - deformation characteristics changes its initial VP form for tense parts (e.g. the operational case $\mathbf{F}_{\mathbf{A a b}}$ ) and asymptotically approaches the original $\mathbf{S J}$ curve, with still growing $\mathbf{F}_{\mathbf{A}}$ force. The straight line SJ corresponds to the deformation in the case when the operating force opens out the bolted joint like a "hinge" - the 3th load case.

The force acting in this case on the bolt may be determined from the formula

$$
\mathrm{F}_{\mathrm{S}}=\frac{\mathrm{a}+\mathrm{v}}{\mathrm{v}} \cdot \mathrm{F}_{\mathrm{A}}
$$

Taking into account that in fact, instead of linear pressure a surface pressure arises in the gap, and the point of lever rotation moves closer to the bolt axis (load case 3 , Fig. 3), the lever arm $\mathbf{v}$ becomes shorter ( $\left.v^{*}\right)$, resulting in greater force acting on the bolt than in the theoretical case.

In the case of eccentric load of the bolted joint the following stresses occur:

$>$ the axial stress and, for commonly used assembling methods - the tensioning torque;

$>$ the tangential (shear) stress and

$>$ the additional bending stress.

Strength of the bolted joints subjected to dynamic load may be significantly reduced in case of application of additional bending stresses. The fatigue fractures are often found on the bolts that gave rise to failures. In case of dynamic strength tests with static bending superposed, bending is generated by oblique washers located under the bolt head and the nut contact surface. Then it may be found that fatigue strength decreases with increasing bending load. The strength reduction becomes more evident the greater is the strength of the bolt material and the bolt tension. In case of eccentric bolt load the disadvantageous effect of bending on the fatigue strength is significant. Although the tests gave no evidence of the preload effect on fatigue strength of the bolts subjected to a combined load (i.e. bending and tension), it was noticed that the preload force is meaningful for assessment of eccentrically loaded bolted joints. It has been proven that flange elements stretched to the yield point may transfer $100 \%$ of dynamic forces, i.e. more than those subjected to the preload force equal to half of that value. Stationary bench tests of bolted joints, even with some restrictions, lead to more than 560 parameter combinations. According to the bench tests conducted so far, the total loss of the preload force occurs after 300 cycles of load changes, for determined maximum vertical displacement (corresponding to loosening of the bolted joint). Notwithstanding, after 2000 load cycles the safety criterion provides for a $20 \%$ reduction in tension as compared to the initial value applied before the tests [1]. The stand for stationary tests of the bolted joints, built at the FH Köln siła eksploatacyjna $\mathbf{F}_{\mathbf{A}}$ przekracza na początku jednostronnego spadku krytycznej wartości $\mathbf{F}_{\text {Aab }}$, to wtedy charakterystyka siła - odkształcenie „opuszcza” swój pierwotny przebieg VP dla napiętych części - np. przypadek eksploatacyjny $\mathbf{2}$ i zbliża się asymptotycznie $z$ dalej wzrastającą siłą $\mathbf{F}_{\mathbf{A}}$ do pierwotnej krzywej SJ. Prosta SJ charakteryzuje odkształcenie dla przypadku, który otwiera połączenie śrubowe pod wpływem działania siły eksploatacyjnej jak ,zawias” (niem. ,Scharnier”) -przypadek obciążenia 3th.

Siłę działającą na śrubę w tym przypadku można wyznaczyć ze wzoru:

$$
\mathrm{F}_{\mathrm{S}}=\frac{\mathrm{a}+\mathrm{v}}{\mathrm{v}} \cdot \mathrm{F}_{\mathrm{A}}
$$

Ponieważ w rzeczywistości w szczelinie (niem „Trennfuge”) dochodzi do nacisków powierzchniowych, a nie do liniowych oraz przemieszcza się miejsce „punktu obrotu dźwigni” bliżej osi śrubyprzypadek obciążenia 3 (rys.3). Ramię dźwigni $\mathbf{v}$ jest przez to krótsze $\left(v^{*}\right)$ i siła na śrubie jest większa, aniżeli w przypadku teoretycznym.

Przy ekscentrycznie obciążonych połączeniach śrubowych występują funkcjonalnie:

$>$ naprężenia poosiowe i dla zwykle stosowanych metod montażowych (moment napinajacy),

$>$ naprężenia styczne (tnące) oraz

$>$ dodatkowo naprężenia zginające.

Wytrzymałość połączeń śrubowych poddanych obciążeniu dynamicznemu, może być znacznie zmniejszona wskutek działania dodatkowych naprężeń zginających. Często można spotkać przełomy zmęczeniowe na śrubach, które były częstą przyczyną przypadków uszkodzeń. W przypadku dynamicznych prób wytrzymałościowych z superpozycją statycznego zginania, obciążenie zginające jest wytwarzane przez podłożenie skośnej podkładki pod główkę śruby i powierzchnię stykową nakrętki i wtedy można stwierdzić, że wytrzymałość zmęczeniowa spada wraz ze wzrostem obciążenia zginającego. Zmniejszenie wytrzymałości jest tym bardziej widoczne, im materiał zastosowany na śruby posiada większą wytrzymałość i im bardziej połączenie jest napięte. Również przy ekscentrycznie obciążonych śrubach znaczący jest negatywny wpływ obciążeń zginających na wytrzymałość zmęczeniową od dodatkowo działających naprężeń. Pomimo, że podczas badań nie stwierdzono wpływu napięcia wstępnego na wytrzymałość zmęczeniową śrub obciążonych w sposób kombinowany, tzn. poddanych zginaniu i rozciaganiu, zwrócono uwagę, że siła napięcia wstępnego jest miarodajną wielkością dla oceny ekscentrycznie obciążonych połączeń śrubowych. Udowodniono, że elementy kołnierzowe, napięte do granicy plastyczności mogą przenieść $100 \%$ wartości sił dynamicznych, a więc więcej niż te, które są napięte siłą zacisku wstępnego, wynoszącym połowę tej wartości. Badania stanowiskowe połączeń śrubowych na 
(University of Technology) is able to generate eccentric movement of the joint in adjustable frequency range of $10 \div 80 \mathrm{~Hz}$. It is noteworthy that in case of most of the tests carried out in accordance with the requirements of DIN 65151 [5] the test frequencies $12.5 \mathrm{~Hz}$ are used. An example of the load applied to a bolted joint subjected to preload force is shown in Fig. 4.

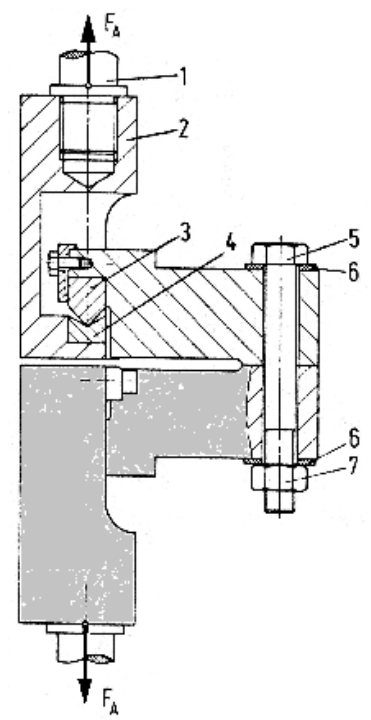

Fig.4. The bolted joint loaded with bending moment on the test bench

Rys.4. Obciążenie momentem zginającym złącza śrubowego na stanowisku badawczym

Meaning of the indexes of Fig. 4: Oznaczenia użyte na rys.4:

1- tensioning pin; 1 - sworzeń rozciagający,

2- load-bearing part; 2- trawersa,

3- cutting edge; 3- ostrze,

4- seat; 4- gniazdo,

5- hexagon nut; 5- nakrętka sześciokątna,

6- washer; 6- podkładka,

7- nut. 7- nakrętka.

\subsection{Recommendations related to selection of bolted} joints used in railway technology

The above-mentioned operating conditions allow to draw the following general conclusions:

$>$ Bolted joints often work under very difficult conditions and are exposed to variable loads, i.e. vibrations of a wide frequency range and variable amplitude, shock loads, that is particularly important in case of rolling stock. It should be noticed here that in the case of the running gear systems the considered frequency range is $2-16 \mathrm{~Hz}$. Taking into account the fatigue strength this range is particularly dangerous, since the deformation in the bolt material can grow to full extent due to longer duration of the vibration.

$>$ Oscillations (vibrations, shocks, vibrations of materials) and bending loads are the factors increasing the risk of loosening of the bolted joint. Vibrations in railway vehicles are of kinematic nature, their amplitude increases with growing speed of the vehicle. Therefore, the acceleration and force stanowiskach stacjonarnych, prowadzą przy już pewnych ograniczeniach do więcej niż 560 kombinacji parametrów. Jak wynika z dotychczas przeprowadzonych badań stanowiskowych wynika, że pełna strata siły zacisku występuje po 300 cyklach obciążeń zmiennych, przy ustaleniu maksymalnego przemieszczenia pionowego (przy którym występuje luzowanie połączenia śrubowego). Natomiast kryterium bezpieczeństwa przewiduje zmniejszenie siły napinającej o $20 \%$ po 2000 cyklach obciążeń, w stosunku do początkowej wartości przed rozpoczęciem prób [1]. Stanowisko do badań stacjonarnych zbudowane w FH Köln (Politechnika) do badań połączeń śrubowych, posiada możliwość wywoływania ekscentrycznego ruchu w regulowanym zakresie częstotliwości, wynoszącym $10 \div 80 \mathrm{~Hz}$. W tym przypadku warto wspomnieć, że w większości prób, które są przeprowadzone zgodnie z wymaganiami normy DIN 65151 [5], stosuje się częstotliwość badawcză, wynosząca $12,5 \mathrm{~Hz}$. Przykład wywierania obciążenia na złącze śrubowe $\mathrm{z}$ zaciskiem wstępnym jest pokazany na rys. 4 .

\subsection{Zalecenia doboru polączeń śrubowych $w$ tech-} nice kolejowej

Z przedstawionych ww. warunków pracy można wyciągnąć następujące wnioski o charakterze ogólnym biorąc pod uwagę, że:

połączenia śrubowe pracują często w bardzo trudnych warunkach i są narażone na obciążenia o charakterze zmiennym tzn. drgania o szerokim zakresie częstotliwości i zmiennej amplitudzie, obciążenia udarowe, co ma szczególne miejsce w taborze kolejowym; należy tutaj zwrócić uwagę że w przypadku układów biegowych zakres częstotliwości, jaki jest brany pod uwagę wynosi $2 \div 16$ $\mathrm{Hz}$; z punktu widzenia wytrzymałości zmęczeniowej jest to zakres szczególnie niebezpieczny, gdyż odkształcenie w materiale śruby może rozwinąć się $\mathrm{w}$ pełnym zakresie $\mathrm{z}$ uwagi na dłuższy okres drgań,

$>$ drgania (wibracje, wstrząsy, drgania materiałowe) obciążenia zginające są czynnikami zwiększającymi prawdopodobieństwo poluzowania się złącza śrubowego; drgania w kolejnictwie mają charakter kinematyczny, zwiększające swoją amplitudę w miarę zwiększających się prędkości poruszającego się pojazdu; jeśli tak to rosną przyspieszenia i siły (amplitudy sił), obciążające złącza śrubowe, zwiększając tym samym ryzyko ich poluzowania lub ich pęknięcia zmęczeniowego,

$>$ istotnym warunkiem prawidłowego rozpoznania warunków pracy złącza śrubowego jest dobranie prawidłowej siły zacisku wstępnego, który realizuje się przez użycie klucza dynamometrycznego i dobór odpowiedniego momentu skręcającego (momentu dokręcania); 
(force amplitude) grow too, resulting in increased load the bolted joints are subjected to. At the same time the risk of loosening or fatigue crack increases.

$>$ An important prerequisite for correct recognition of the working conditions of a bolted joint is adjustment of the correct preload force. This is achieved by the use of a torque wrench and adjustment of proper torque (tightening torque). The condition of proper operation of the bolted joint and its safety elements comes down to its correct assembly.

$>$ An important factor affecting the rail vehicles is corrosion, being the more significant the more the bolted joint is exposed to the weather conditions. Proper protection of the bolted joints and their parts is a condition of their unscrewing and further use. Excessive corrosion of the bolted joint results in reduction in its load capacity and serious difficulties in its unscrewing (e.g. in the case of connecting the bogie pivot to the freight car body, the bolted joints had to be burned-off, thus precluding their reuse). Therefore, an important role is played by corrosion protection, defined as protection of bolts by galvanizing, quenching and tempering, covering with zinc (zinc flakes), protective layers containing hexavalent $\mathrm{Cr}$, zincaluminum protective coatings containing hexavalent $\mathrm{Cr}$, etc.

$>$ The bolt tensioning moment should be provided together with the information on the lubricant specified in the design documentation, as otherwise it leads to inaccurateness and errors. Should the tensioning moment of the considered bolted joint be indicated in the structural drawing, it is necessary to specify the lubricant, inclusive of synthetic oil based lubricating pastes with solid lubricants $\left(\mathrm{MoX}, \mathrm{MoS}_{2}\right.$ - molybdenum disulphide, mineral oil based paste in combination with solid lubricants, assembly paste in combination with aluminum lubricant.

$>$ In case of using the flat washers according to DIN EN ISO 7093-1 [8], the condition of their correct operation requires the washer hardness equal to $200 \mathrm{HV}$ in case of the strength class $\leq 8.8$ and 300 $\mathrm{HV}$ in case of the strength class over 8.8 , in accordance with the Annex A of DIN 25201-4 [7]. Nevertheless, the above mentioned conditions must comply with the essential principle requiring the washer hardness to be lower than that of the

$>$ settle surfaces of the bolt head, nuts and preloaded elements.

\section{INTERNATIONAL REGULATIONS RE-} LATED TO THE BOLTED JOINTS warunkiem poprawnej pracy złącza śrubowego i jego elementów zabezpieczających jest prawidłowe, jeżeli montaż połączenia śrubowego jest prawidłowy,

> istotnym czynnikiem, który może działać w pojazdach kolejowych jest korozja, która jest tym bardziej istotna im bardziej złącze śrubowe jest nastawione na działanie czynników atmosferycznych; prawidłowe zabezpieczenie złącz śrubowych i ich elementów śrubowych jest warunkiem prawidłowego ich odkręcenia i dalszego użytkowania; nadmierna korozja postępująca w złączu śrubowym powoduje ograniczenie nośności złącza śrubowego oraz poważne trudności $\mathrm{w}$ ich odkręceniu (np. $\mathrm{w}$ przypadku połączenia czopa skrętu $\mathrm{z}$ nadwoziem wagonu towarowego złącza śrubowe trzeba było upalać, co wykluczało ponowne ich zastosowanie); w związku z powyższym ważną rolę odgrywa zabezpieczenie antykorozyjne przez co rozumie się zabezpieczenie śrub przez cynkowanie galwaniczne, ulepszanie cieplne; pokrycie za pomoca warstw ochronnych cynkowych (płatków cynkowych) zawierających Cr (VI. wartościowy), powłok warstw ochronnych cynkowo-aluminiowych, zawierających Cr (VI wartościowy) itd.,

podawanie momentu napinającego śruby bez informacji o użytym środku smarnym $\mathrm{w}$ dokumentacji konstrukcyjnej jest nieścisłe i błędne; jeśli na rysunku konstrukcyjnym jest podany moment napinający, dotyczący danego połączenia śrubowego to konieczne jest podanie środka smarnego, do których należą pasty smarne na bazie oleju syntetycznego ze stałymi środkami smarnymi (MoX, $\mathrm{MoS}_{2}-$ dwusiarczek molibdenu, pastę na bazie oleju mineralnego $\mathrm{w}$ kombinacji ze stałymi materiałami smarnymi, pasta montażowa $\mathrm{w}$ kombinacji $\mathrm{z}$ aluminiowym środkiem smarnym,

> jeśli stosuje się płaskie podkładki zgodnie $\mathrm{z}$ norma DIN EN ISO 7093-1 [8], to warunkiem poprawnej pracy złącza śrubowego jest stosowanie podkładek o twardości $200 \mathrm{HV}$ dla klasy wytrzymałości $\leq 8.8$ oraz o twardości $300 \mathrm{HV}$ dla śrub o klasie wytrzymałości powyżej 8,8 zgodnie z załącznikiem A normy DIN 252014 [7]. Jednak wyżej wymienione warunki muszą spełniać warunek zasadniczy, polegający na tym, że twardość podkładek musi być mniejsza, aniżeli powierzchnie osadcze łba śruby, nakrętki i elementów poddanych napięciu wstępnemu. 
Substantive scope of international regulations related to strength of bolted joints in rail industry is limited, although, as mentioned earlier, these regulations play an important role in the field of operational safety. The UIC 802-72 card [11] issued in 1995 does not comply with the current state of technology and requires further study and re-edition. UIC 802-70 [9] and UIC 802-71 [10] cards were cancelled on January 1, 1994. On the other hand, in the scope of European standards, the standard PN-EN 61373: 2011 [4] seems to be reliable, although it does not refer to them directly. The DIN 65151 standard [5] referring to the strength of the bolts used in the aviation industry is of great importance, nevertheless, it can also be successfully used in rolling stock. The analysis carried out till now demonstrates a need of formulation of a document devoted to the bolted joints used in rolling stock, in which their specific features would be taken into account. Despite other factors it should be noticed that monitoring of the railway vehicles, due to their specificity, is not so effective as that of stationary devices. The use of acceleration sensors to be mounted at various locations on the vehicle board in the coming years may provide only partial solution to the problem, particularly in case of the bolted joints.

\section{CONCLUSIONS}

1. Reliability of rolling stock vehicles results from high durability of their particular assemblies, sub-assemblies, parts and components. These groups certainly include the bolted joints existing in the wheelsets, bogies and freight car bodies that play a very important role. Operation of the vehicle results in extreme static loads of these elements, namely random vibrations and dynamic loads. The nodes containing the bolted joints are often repeatable within the construction. Therefore, any optimization efforts related thereto are of economic nature as the running gears are almost entirely or fully standardized.

2 A new offer of screws (the screws of various head shapes), lock washers and multiple-use nuts comes on the railway market that may be considered positive. Nevertheless, the lack of uniform rules allowing to qualify these products for rail operation is evident. As a result, the differences in the scope of approval requirements for placing in service of freight wagons arise, even provided that the approval is carried out in accordance with the provisions of the TSI (rules for interoperability). Another often ignored thing is that organization of operation and repairs is decisive for safety of the bolted joints. The ideal solution would consist in adoption of the principle requiring the repairs of the rail vehicles in the

\section{PRZEPISY MIECDZYNARODOWE DOTY- CZĄCE POLĄCZEŃ ŚRUBOWYCH}

Przepisy międzynarodowe, dotyczące wytrzymałości połączeń śrubowych w kolejnictwie maja ograniczony zakres pod względem merytorycznym, choć tak jak wspomniano wcześniej pełnią one istotną rolę w zakresie bezpieczeństwa eksploatacyjnego. Karta UIC 802-72 [11] wydana w 1995 roku nie odpowiada aktualnemu stanowi techniki i wymaga kolejnych prac studialnych oraz zredagowania następnego wydania. Karty UIC 802-70 [9] i UIC 802-71 [10] zostały unieważnione $\mathrm{z}$ dniem 01.01.1994. Z kolei w zakresie norm europejskich o miarodajna wydaje się norma tzn. PN-EN 61373:2011 [4], choć bezpośrednio do nich się nie odnosi. Spore znaczenie ma norma DIN 65151 [5], która odnosi się do wytrzymałości śrub zastosowanych $\mathrm{w}$ przemyśle lotniczym, ale $\mathrm{z}$ powodzeniem może być również stosowana $\mathrm{w}$ taborze kolejowym. $Z$ przeprowadzonej analizy wynika jasno, że potrzeba jest opracowania dokumentu poświęconemu połączeniom śrubowym $\mathrm{w}$ taborze kolejowym, który uwzględniałby jego specyfikę zastosowania. Należy chociażby uwzględnić poza innymi już wymienionymi, że pojazdy kolejowe $\mathrm{z}$ racji pełnionej funkcji, nie mają takiej możliwości monitorowania jak urządzenia stacjonarne. Planowane zastosowanie czujników przyspieszeń, montowanych na pokładzie pojazdu w różnych miejscach $\mathrm{w}$ najbliższych latach, może dać tylko częściowe rozwiązanie problemu, zwłaszcza dla połączeń śrubowych.

\section{WNIOSKI}

1. Niezawodność pojazdów taboru kolejowego, jest wynikiem wysokiej trwałości ich poszczególnych zespołów, podzespołów, elementów/komponentów. Do takich grup konstrukcyjnych można zaliczyć z pewnością połączenia śrubowe, które występują w zestawach kołowych, wózkach oraz na nadwoziach wagonu towarowego. Połączenia te pełnią bardzo odpowiedzialną rolę. Podczas eksploatacji w węzłach tych występują ekstremalne obciążenia statyczne, wibracje losowe oraz obciążenia dynamiczne. Węzły z połączeniami śrubowymi są często powtarzalne pod względem konstrukcyjnym. W związku z powyższym wszelkie zabiegi i optymalizacyjne w tym kierunku można uważać za ekonomiczne, ponieważ układy biegowe posiadają konstrukcję quasi- lub całkowicie standardowa.

2. Za pozytywny można uznać fakt pojawiania się na rynku kolejowym coraz to nowej oferty śrub (kształt łba śruby), podkładek zabezpieczających oraz nakrętek wielokrotnego stosowania. Towarzyszy temu jednak brak jednolitych przepisów, które pozwoliłyby kwalifikować te produkty do eksploatacji kolejowej. W wyniku tego można 
entire P1-P5 range to be carried out by the rolling stock manufacturer. Such practices are used in European and global railways. In such a case only one institution is in practice responsible for proper operation of the construction and maintenance of its proper technical condition. The more often the bolted joint is disassembled and mounted by various institutions, the greater the likelihood of a mistake. Can the principle be presumed, that those who perform simplified ultrasonic test of the rail vehicle wheelset axles are sufficiently professional to know what tightening moment should be applied in order to screw it again? This issue is raised as these tests are carried out by the carrier personnel. Such tests may be carried out without disassembling the bogies from the locomotive/trainset/passenger car /freight car and can be carried out in "field conditions".

3 According to development trends of the rail vehicles the stationary tests of bolted joints can no longer be fully accepted due to the required availability of the rail vehicles. It is caused by the development of modern constructions of ultra-light rail vehicles. In result, the installation and assembly space is limited to such a degree that the $\mathrm{L}_{\mathrm{K}}$ clamp length is reduced. Thus, the dynamic load acting on the bolted joint gives rise to higher risk of its spontaneous loosening than in case of those distinguished by larger clamp length values. Accordingly, special construction measures should be applied in such a case, consisting in the use of gluing as an auxiliary technology as well as elastic or shaped locking washers.

4 When designing bolted joints the operating specificity of the vehicle should be taken into account. Long-distance units have a record mileage of $500,000 \mathrm{~km}$, the locomotives and passenger cars approx. $200,000 \div 250,000 \mathrm{~km}$, while the freight wagons $25,000 \div 40,000 \mathrm{~km}$ on an annual basis. Nonetheless, the passenger multiple units, locomotives and passenger cars are more frequently surveyed than the freight cars.

\section{BIBLIOGRAPHY / BIBLIOGRAFIA}

[1] Franke R.; Gärtner E.; Klöckner M.: Funktionssicherheit von Schraubenverbindungen mit Sicherheitselementen für Sicherungselementen für Schienenfahrzeuge. (pol. „Bezpieczeństwo funkcjonalne połaczeń śrubowych z elementami zabezpieczajacymi dla pojazdów szynowych). ZEV Rail Glasers Annalen Nr.132 Mai 2008.

[2] Sobaś M.: Wplyw omaźnicowanych zestawów kołowych na bezpieczeństwo eksploatacyjne. Pojazdy Szynowe $n r$ 4/2016. mówić o różnicach w zakresie wymagań homologacyjnych w zakresie dopuszczenia do eksploatacji wagonów towarowych, nawet jeśli homologacja odbywa się wg przepisów TSI (przepisów interoperacyjności). Kolejnym faktem, który często nie bywa uwzględniany jest fakt, że bezpieczeństwo połączeń śrubowych wynika $\mathrm{z}$ organizacji eksploatacji oraz napraw. Idealnym rozwiązaniem byłoby przyjęcie zasady: ,producent taboru kolejowego jest zakładem naprawiającym pojazdy szynowe w całym zakresie P1P5" Takie praktyki są stosowane w kolejnictwie europejskim oraz światowym. Wtedy odpowiedzialna za prawidłowe funkcjonowanie konstrukcji oraz utrzymanie prawidłowego stanu technicznego jest praktycznie jedna instytucja. Im częściej połączenie śrubowe jest demontowane i montowane przez różne instytucje tym prawdopodobieństwo wystapienia błędu jest większe. Czy można przyjąć zasadę, że przeprowadzający uproszczone badania ultradźwiękowe osi zestawów kołowych pojazdów szynowych mają wystarczająca wiedzę, z jakimi momentami napinającymi należy $\mathrm{z}$ powrotem je przykręcić? Kwestia ta jest poruszona $\mathrm{z}$ uwagi na fakt, że badania te są przeprowadzane przez personel, reprezentujący przewoźnika. Badania te mogą się odbywać bez wywiązywania wózków spod lokomotywy/zespołu trakcyjnego/ wagonu osobowego/wagonu towarowego i mogą być przeprowadzone $\mathrm{w}$,warunkach poligonowych".

3. Jak wynika $z$ tendencji rozwojowych pojazdów szynowych, badania stacjonarne połączeń śrubowych nie mogą być już w pełni akceptowane z uwagi na wymaganą dyspozycyjność pojazdów szynowych. Powodem jest rozwój nowoczesnych konstrukcji ultralekkich pojazdów szynowych. W wyniku tego przestrzenie do zabudowy i montażu są tak ograniczone, że prowadzi to do zmniejszenia długości zacisku $\mathrm{L}_{\mathrm{K}}$. Przy dynamicznych obciążeniach, działających na połączenia śrubowe występuje ryzyko samoczynnego luzowania w porównaniu do tych, które posiadają większe długości zacisku. W związ$\mathrm{ku} \mathrm{z}$ powyższym należy stosować $\mathrm{w}$ tym przypadku specjalne środki konstrukcyjne, które sprowadzają się do używania klejenia jako technologii pomocniczej oraz podkładek zabezpieczających sprężystych lub kształtowych.

4. Przy projektowaniu połączeń śrubowych należy uwzględnić specyfikę eksploatacyjną danego pojazdu. Zespoły trakcyjne dalekobieżne osobowe posiadają rekordowe przebiegi wynoszące $500000 \mathrm{~km}$, lokomotywy i wagony osobowe ok. $200000 \div 250000 \mathrm{~km}$, natomiast wagony towarowe $25000 \div 40000 \mathrm{~km} \mathrm{w}$ skali rocznej. 
[3] Tauscher H.: Dauerfestigkeit von Stahl und Gusseisen. 4.; neubearbeitete Auflage. VEB Fachbuchverlag Leipzig 1982.

[4] PN-EN 61373:2011: Zastosowanie kolejowe. Wyposażenie taboru kolejowego. Badania odporności na udary mechaniczne $i$ wibracje.

[5] DIN 65151: Luft-und Raumfahrt-Dynamische Prüfung des Sicherungsverhalten von Schraubenverbindungen unter Querbeanspruchung (Vibrationsprüfung). Deutsches Institut für Normung. Ausgabe; August 2002.

[6] DIN 267-26: Fasteners - Technical specifications Part 26: Conical spring washers for bolted connections.

[7] DIN 25201-4: Konstruktionsrichtlinie für Schienenfahrzeuge und deren Komponenten Schraubenverbindungen- Sichern von Schraubenverbindungen. Deutsches Institut für Normung. Ausgabe Juni 2004.
Zespoły trakcyjne osobowe, lokomotywy oraz wagony osobowe maja jednak częstsze przeglądy w stosunku do wagonów towarowych.

[8] DIN EN ISO 7093-1 :Flache Scheiben-Große ReiheTeil 1: Produktklasse A. Deutsches Institut für Normung; Ausgabe November 2000.

[9] Karta UIC 802-70: Mechanical characteristics of bolts, screws and nuts. Cancelled on 1.01.2004

[10] Karta UIC 802-71: Mechanical stainless steel fasteners (hexagonal head screws and nuts). Cancelled on 1.01.2004.

[11] Karta UIC 802-72: Zabezpieczenie połaczeń śrubowych. Wydanie 1. 01.01.1995. 